The Rangeland Journal, 2012, 34, 47-53

http://dx.doi.org/10.1071/RJ11021

\title{
Native forb response to sulfometuron methyl on medusahead-invaded rangeland in Eastern Oregon
}

\author{
Mounir Louhaichi ${ }^{\mathrm{A}, \mathrm{B}, \mathrm{E}}$, Michael F. Carpinelli ${ }^{\mathrm{C}}$, Lesley M. Richman ${ }^{\mathrm{D}}$ \\ and Douglas E. Johnson ${ }^{\mathrm{A}}$ \\ A Department of Rangeland Ecology and Management, Oregon State University, \\ Corvallis, OR 97331, USA. \\ ${ }^{B}$ International Centre for Agricultural Research in the Dry Areas (ICARDA), Aleppo, Syria. \\ ${ }^{C}$ Current address: USDA/Forest Service, Albuquerque, NM 87113, USA, \\ Formerly Agricultural Research Service, EOARC, Burns, OR 97720, USA. \\ DUSDI/Bureau of Land Management, Burns, OR 97720, USA. \\ ${ }^{\mathrm{E} C}$ Corresponding author. Email: M.Louhaichi@cgiar.org
}

\begin{abstract}
Medusahead [Taeniatherum caput-medusae (L.) Nevski], a non-native, winter-annual grass (Poaceae), has invaded rangelands throughout the western USA. Medusahead is an aggressive competitor that crowds out native plants and reduces forage for wildlife and livestock. Sulfometuron methyl is a sulfonylurea herbicide used to control medusahead, but its effect on non-target native forbs is largely unknown. We assessed the impact of an autumn application of sulfometuron methyl on native forbs on the sagebrush/bunchgrass steppe of eastern Oregon over 3 years. We applied $70 \mathrm{~g}$ a.i./ha $(1.0 \mathrm{oz}$. a.i./acre) of sulfometuron methyl to randomly selected locations on three sites in a split-plot-in-time (repeated-measures) experimental design. Three years after treatment, 6 of the 11 forb species studied had a significant reduction in density $(P<0.05)$, with densities ranging from 3 to $60 \%$ of the pre-treatment levels. The results of this study suggest that the benefit of medusahead control by sulfometuron methyl should be weighed against the damage to non-target species.
\end{abstract}

Additional keywords: Great Basin, image processing, invasive annual grass, non-target, Oust, population dynamics, Taeniatherum caput-medusa, VegMeasure.

Received 24 April 2011, accepted 3 August 2011, published online 29 February 2012

\section{Introduction}

In the United States, an estimated 5000 introduced plant species have escaped and now exist in natural ecosystems, compared with a total of $\sim 17000$ species of native plants (Pimentel 2002). Oregon's High Desert Ecological Province is being invaded by exotic plant species that threaten its native plants and biotic diversity (Anderson et al. 1998; Monaco et al. 2005). One of the more problematic species is medusahead [Taeniatherum caput-medusae (L.) Nevski], an aggressive winter-annual grass introduced from Eurasia that has spread over millions of hectares in the semiarid west (Whitson et al. 2002; Davies 2010). In Harney County, Oregon, most of the area being invaded by medusahead is on clayey rangeland in otherwise fair to excellent condition and dominated by late-seral, native vegetation (USDI Bureau of Land Management 2001; USDA Forest Service 2005). The land area dominated by medusahead is increasing, as are impacts on native plant communities (James et al. 2008). Forage losses resulting from medusahead expansion impact both domestic animals and wildlife species including greater sage grouse (Centrocercus uruphasianus). Several studies have reported that medusahead-dominated ranges have suffered 40-90\% reductions in grazing capacity (Major et al. 1960; Hironaka 1961; Davies and Svejcar 2008). It is therefore imperative that efforts be made to control medusahead and protect plant communities that are at risk from invasion.

At the time this study was initiated, sulfometuron methyl (methyl 2-[[[[(4,6-dimethyl-2-pyrimidinyl) amino] carbonyl] amino] sulfonyl] benzoate) was commonly recommended to control medusahead on rangelands. Sulfometuron methyl belongs to the chemical family Sulfonylurea (Vallentine 2004; USDA Forest Service 2007). The composition of the product is $75 \%$ sulfometuron methyl and $25 \%$ inert ingredients. It is classified as broad-spectrum herbicide for noncropland and forestry use (SERA 2004). Sulfometuron methyl inhibits acetolactate synthase (ALS), an enzyme that catalyzes the biosynthesis of three branched-chain 215 amino acids, all of which are essential for plant growth (Bahm et al. 2011; USDA Forest Service 2004). It is most effective when applied before (pre-emergent) or during (early post-emergent) the early stages of weed growth (Harvey et al. 1985; Trubey et al. 1998). 
Sulfometuron methyl is effective in controlling invasive weeds, including medusahead (Donaldson and Bowers 1998; USDA Forest Service 2008). On rangelands, sulfometuron methyl is mainly used to control broadleaf weeds and annual grasses (Russell et al. 2002). Because of site inaccessibility during the spring treatment window, the Bureau of Land Management (BLM) was interested in sulfometuron methyl for medusahead control as it has residual effect (Harvey et al. 1985) and can be applied in the autumn. While controlling medusahead with sulfometuron methyl is intended to indirectly benefit native plant populations, it may directly harm these same plant populations. At low rates $(1 \mathrm{oz}$./acre) sulfometuron methyl can effectively control annual grasses without killing the perennial grasses. As we considered using sulfometuron methyl for medusahead control, we were concerned by the lack of information on the impacts on associated native forb species of the High Desert Ecological Province.

The objective of this study was to assess the density response of selected native forbs to sulfometuron methyl in eastern Oregon. Of special interest were forbs that included 'Bureausensitive' species occurring on public lands in the Burns District of the BLM. Bureau-sensitive species include not only endangered and threatened species listed by the United States Fish and Wildlife Department but also species of concern by the BLM. We hypothesised that sulfometuron methyl reduces forb density. This experiment was not designed to evaluate the effectiveness of medusahead control by sulfometuron methyl.

\section{Materials and methods}

\section{Site description}

The study was conducted in the Northern Great Basin, Harney County, Oregon. Three sites were chosen because they had rich populations of native forbs and have been invaded by medusahead. The Sage Hen Site is $25 \mathrm{~km}$ west of Burns, Oregon (lat. $43.5625^{\circ} \mathrm{N}$, long. $119.3631^{\circ} \mathrm{E}$ ). It is a mid-seral native perennial grassland characterised by Bluebunch wheatgrass [Pseudoroegneria spicata (Pursh) A. Löve], Thurber's needlegrass [Achnatherum thurberianum (Piper) Barkworth], Idaho fescue (Festuca idahoensis Elmer), California oatgrass (Danthonia californica Bol.), Squirreltail [Elymus elymoides (Raf.) Swezey ssp. Elymoides], Wyoming big sagebrush (Artemisia tridentata ssp. wyomingensis Beetle \& Young), and Little sagebrush (Artemisia arbuscula Nutt.). The Warm Springs Site is $65 \mathrm{~km}$ east of Burns, Oregon (lat. $43.5833^{\circ} \mathrm{N}$, long. $\left.118.2911^{\circ} \mathrm{E}\right)$. It is characterised by mid- to late seral Wyoming big sagebrush/perennial grassland ( $65 \%)$, earlyto late seral Rubber rabbitbrush [Ericameria nauseosa (Pall. ex Pursh) G.L. Nesom \& Baird]/grassland ( 30\%), and mid- to late seral Little sagebrush (Artemisia arbuscula Nutt.)/grassland ( 5\%). Dominant plant species include Wyoming big sagebrush, Bluebunch wheatgrass, Thurber's needlegrass, Idaho fescue, Squirreltail, Green rabbitbrush [Ericameria teretifolia (Durand \& Hilg.) Jeps.], Rubber rabbitbrush, and Little sagebrush. The Riddle Mountain Site is $70 \mathrm{~km}$ south-east of Burns, Oregon (lat. $43.0817^{\circ} \mathrm{N}$, long. $118.5278^{\circ} \mathrm{E}$ ). It is a mid-seral shrub/ grassland characterised by Wyoming big sagebrush, Bluebunch wheatgrass, Thurber's needlegrass, Idaho fescue, and Squirreltail. Most precipitation comes in winter, with most of the remainder coming in late spring and early summer. The mid to late summer is warm and dry. The long-term average annual precipitation is $\sim 260 \mathrm{~mm}$.

\section{Experimental procedure}

Population dynamics of native plants in Oregon's High Desert Ecological Province are often difficult to predict, given the erratic expression of many species depending on the climatic conditions of a given year (Anderson et al. 1998). We accounted for the variable annual forb expression by employing paired permanent plots that were monitored over several years. Our experimental design included two treatments: a herbicide treatment and an untreated control. We established paired plots with similar initial forb compositions. Because some species were more abundant than others, some forb species occurred in more paired plots than others. Some paired plots contained several of the forb species studied, while others contained only one. Eleven forb species were evaluated (Table 1).

We applied a moderate, label-recommended (DuPont Agricultural Products 2002) rate for medusahead of $70 \mathrm{~g}$ a.i./ha (1.0 oz. a.i./acre) of sulfometuron methyl to randomly selected locations on three sites in a split-plot-in-time (repeated-measures) experimental design. Plots with similar slope, soil, and aspect containing the same forb species at like densities were paired to ensure that native plant populations were similar across treatments. A total of 65 , paired, $1-\mathrm{m}^{2}$ plots were chosen at the Riddle Mountain, Sage Hen, and Warm Springs sites (16, 24, and

Table 1. List of forb species included in the study

\begin{tabular}{ll}
\hline Common name & Scientific name \\
\hline Pale agoseris & Agoseris glauca (Pursh) Raf. \\
Onion & Allium spp. \\
Woollypod milkvetch & Astragalus purshii Dougl. ex Hook. \\
Serrate balsamroot & Balsamorhiza serrata A. Nels. \\
& and J.F. Macbr. \\
Sagebrush mariposa lily & Calochortus macrocarpus Dougl. \\
Rock lupine & Lupinus saxosus T.J. Howell \\
Sagebrush false dandelion & Phlocalais troximoides (Gray) Greene \\
Spiny phlox & Phlox longifolia Nutt. \\
Longleaf phlox & Trifolium macrocephalum (Pursh) Poir. \\
Largehead clover & Zigadenus paniculatus (Nutt.) S. Watson \\
Foothill deathcamas &
\end{tabular}

Table 2. $P$-value of forbs density (plants $/ \mathrm{m}^{2}$ ) on control and treated plots over the study period

\begin{tabular}{llrr}
\hline Species & Family & $n$ & $P$ \\
\hline Pale agoseris & Asteraceae & 7 & 0.001 \\
Onion & Liliaceae & 6 & 0.019 \\
Woollypod milkvetch & Fabaceae & 6 & 0.068 \\
Serrate balsamroot & Asteraceae & 7 & 0.001 \\
Sagebrush mariposa lily & Liliaceae & 5 & 0.083 \\
Rock lupine & Fabaceae & 12 & $<0.001$ \\
Sagebrush false dandelion & Asteraceae & 7 & 0.403 \\
Spiny phlox & Polemoniaceae & 6 & 0.017 \\
Longleaf phlox & Polemoniaceae & 13 & 0.007 \\
Largehead clover & Fabaceae & 12 & 0.703 \\
Foothill deathcamas & Liliaceae & 5 & 0.290 \\
\hline
\end{tabular}


25 plots, respectively). Each plot was positioned to within $1 \mathrm{~m}$ of the actual location with a Trimble Pathfinder Pro XR DGPS unit (Sunnyvale, CA, USA), and two opposite corners of each plot were staked. In the autumn of 2001, sulfometuron methyl was applied via a backpack sprayer to one plot randomly selected from each pair. Sulfometuron methyl is typically applied in the autumn because medusahead germinates from late autumn through early spring and, from a practical standpoint, because medusahead-invaded rangelands in Harney County are often impassable in the early spring because of the wet clay substrate. Also, forb species are typically dormant in the autumn but begin growth early in the spring. The autumn application was expected to reduce the likelihood of non-target damage.

Field sampling occurred in late May of 2001 (pre-treatment), 2002, 2003, and 2004. The species composition of the forbs in each plot was recorded, as well as the density of each species. In order to determine the impact of sulfometuron methyl on plant growth, all plots were photographed following the digital vegetation charting technique (Louhaichi et al. 2001, 2010). All images were analysed using VegMeasure software (Johnson et al. 2003; Booth et al. 2005) for green leaf cover (percent). VegMeasure is a computerised vegetation measurement program, stemming from research conducted by the Department of Rangeland Ecology and Management at Oregon State University that measured vegetative cover on rangelands, agronomic fields, and riparian areas.

Data from the sulfometuron methyl treatments and controls were analysed using the generalised model procedure (McCullagh and Nelder 1989; SAS 2009). Poisson regression is similar to regular regression, except that the dependent variable (y) follows the Poisson distribution and the log of the mean of the Poisson distribution has a linear model form. We assumed a Poisson distribution for count data. More precisely, we modelled the $\log$ of the expected count (density) for each species as a
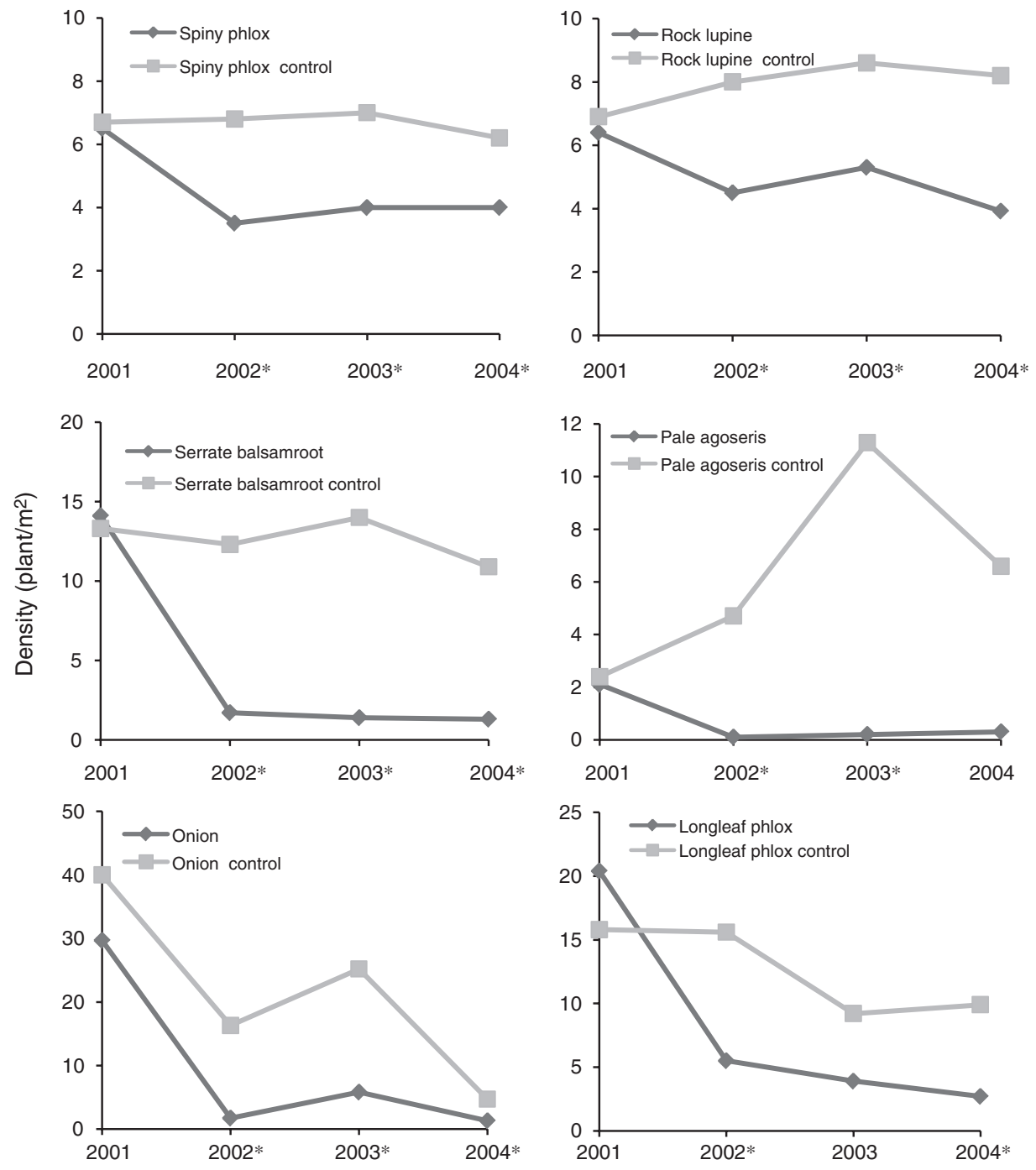

* The differences between the control and treated were significant $(P<0.05)$.

Fig. 1. Forb species showing significant reduction in density $(P<0.05)$ due to sulfometuron methyl on medusahead-invaded rangeland in eastern Oregon over the study period. 

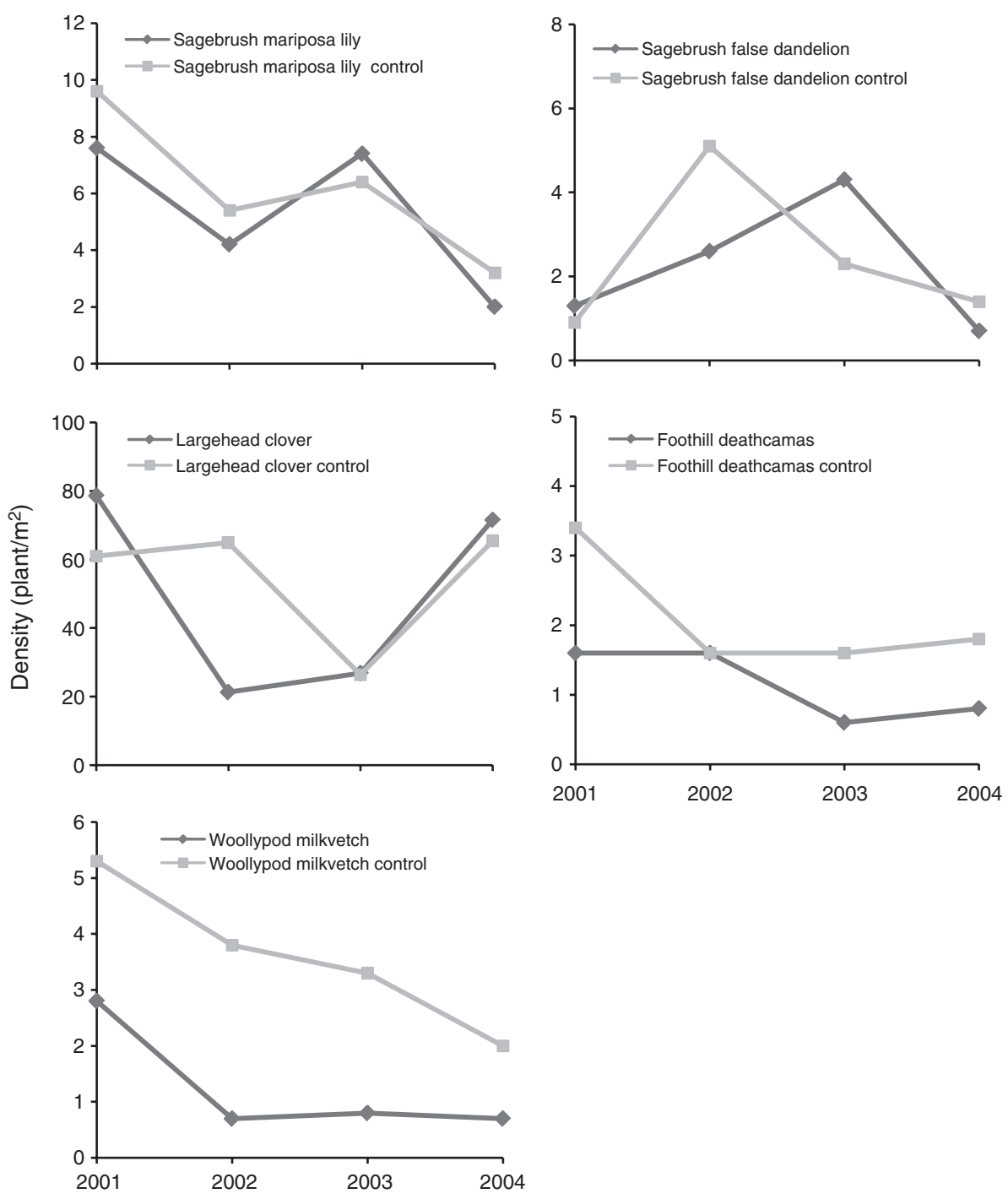

Fig. 2. Forb species showing non-significant reduction in density $(P<0.05)$ due to sulfometuron methyl on medusahead-invaded rangeland in eastern Oregon over the study period.

linear model with factors including: site, pair (treatment pair of plots), year, treatment, and treatment within year. Year is the repeated-measures factor. To identify the repeated-measures factor, the 'subject' corresponds to the plot to which the treatment was applied, and within the plot, the 'count' corresponds to the year of observation. We used the autoregressive correlation type option for the repeated-measures. The model is as follows:

$$
\begin{aligned}
& \text { Log }(\text { Expected Count for a Species })=\mu+\text { Site }+ \text { Pair }(\text { Site }) \\
& + \text { Year }+ \text { Treatment }(\text { Year })
\end{aligned}
$$

where only sites that contained at least one of the forb species studied were analysed.

The number of parameters for each factor is equal to the number of categories for that factor minus 1. Each forb species was analysed independently. Population change was calculated by dividing the number of forb species in the treated plots by their number in their respective paired (control) plots. A $P<0.05$ was accepted as significant in all analyses.

\section{Soil sampling}

Sulfometuron methyl efficacy is affected by soil organic matter, clay content, and pH (DuPont Agricultural Products 2002). To help explain potential site differences in forb response to treatment, systematic-randomly located $483-\mathrm{mL} \quad(63.5 \mathrm{~mm}$

Table 3. Soil attributes by site

\begin{tabular}{|c|c|c|c|c|c|c|}
\hline \multirow[t]{3}{*}{ Site } & \multirow{2}{*}{\multicolumn{2}{|c|}{$\begin{array}{c}\text { Organic } \\
\text { matter (\%) }\end{array}$}} & \multicolumn{2}{|c|}{ Clay } & \multicolumn{2}{|c|}{$\mathrm{pH}$} \\
\hline & & & \multirow{2}{*}{ Mean } & \multirow[t]{2}{*}{ Group } & \multirow[t]{2}{*}{ Mean } & \multirow[t]{2}{*}{ Group } \\
\hline & Mean & Group & & & & \\
\hline Sage Hen & 4.31 & A & 23.1 & B & 6.89 & B \\
\hline Warm Springs & 4.55 & A & 31.2 & A & 7.45 & A \\
\hline Riddle Mountain & 4.91 & A & 22.6 & B & 7.37 & A \\
\hline
\end{tabular}

Attributes with same group letter are similar. Duncan's test; $P<0.05$ 


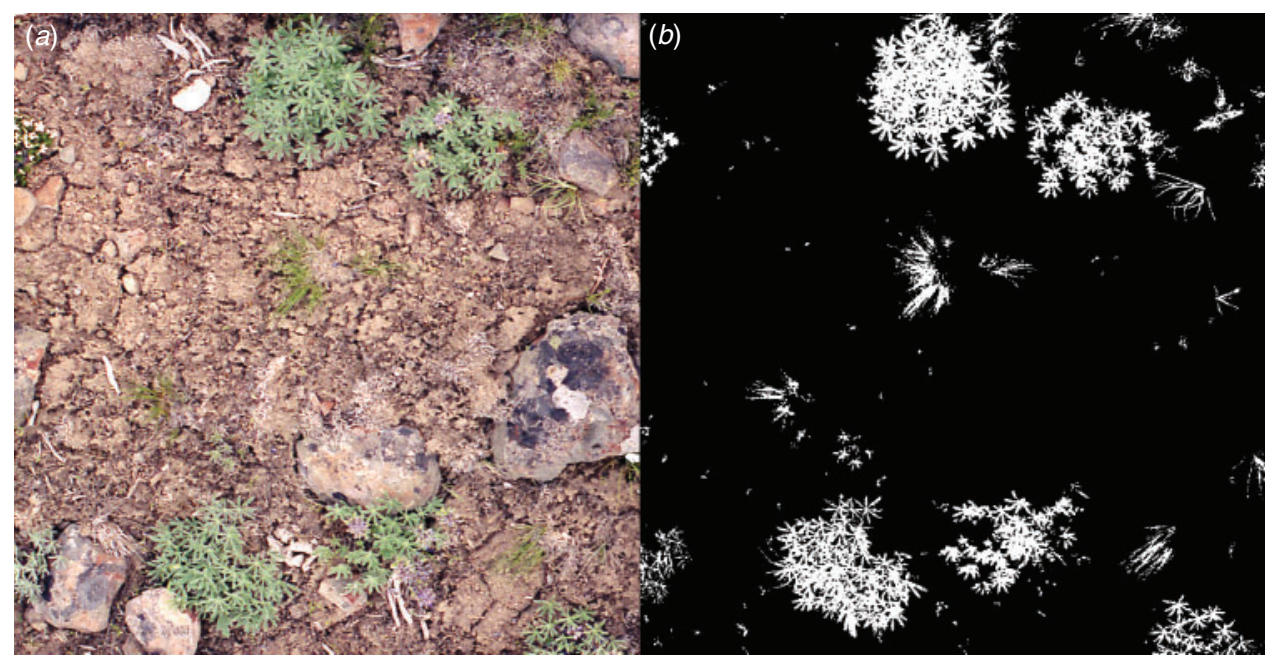

Fig. 3. Estimation of percent vegetation cover of rock lupine: $(a)$ original image, and $(b)$ processed image.

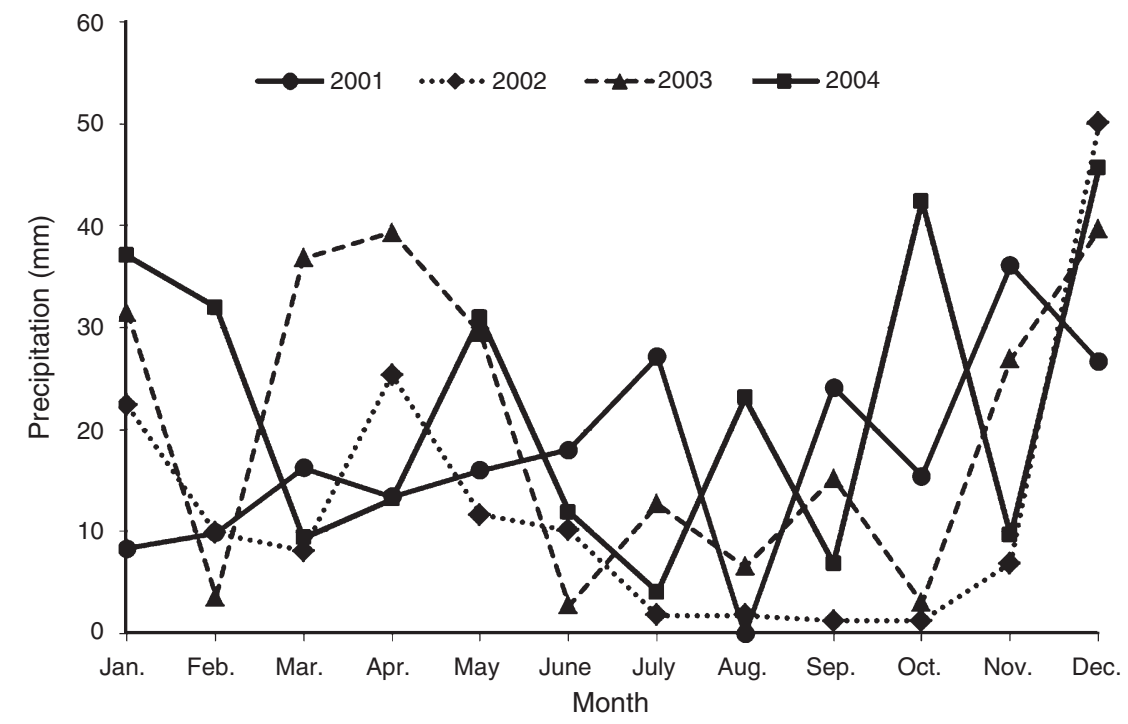

Fig. 4. Monthly precipitation ( $\mathrm{mm}$ ) during the study period (Western Regional Climate Center 2005; BURNS WSO AP, OREGON Station 351175).

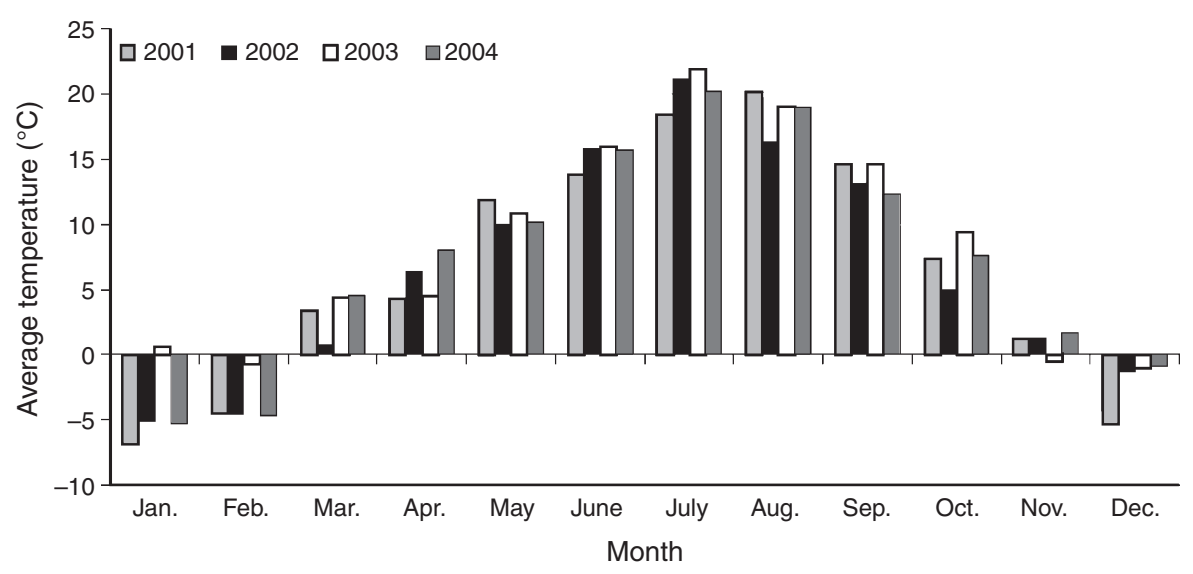

Fig. 5. Monthly average temperature $\left({ }^{\circ} \mathrm{C}\right)$ during the study period (Western Regional Climate Center 2005; BURNS WSO AP, OREGON Station 351175). 
diameter by $152 \mathrm{~mm}$ depth) soil samples were taken at each site in untreated soil in May 2004 (five, six, and eight samples at Sage Hen, Riddle Mountain, and Warm Springs, respectively). General areas were identified that best represented the soil and vegetation of the paired plots at each site, and soil sample locations were randomly located within these general areas. Soil was dried and sieved through a 20 -mesh sieve. Site differences in soil organic matter, clay content, and $\mathrm{pH}$ were analysed using the SAS GLM procedure (Duncan's test) (SAS 2009).

General research findings of sulfometuron methyl characteristics related to the soil resource indicate that it takes 10-100 days for the soil microbes to degrade. The activation mechanism includes acetolactate synthesis inhibitor (nonselective pre- and post-emergent - uptake by roots and leaves).

\section{Results}

Six of 11 forbs tested had a significant reduction (Table 2) in density compared with controls when measured the third spring following treatment (Fig. 1). The five species that were not impacted by sulfometuron methyl were woollypod milkvetch, sagebrush mariposa lily, sagebrush false dandelion, largehead clover, and foothill deathcamas (Fig. 2). There was considerable difference in sulfometuron methyl impact by species and by year. Except for largehead clover and foothill deathcamas, all forb species showed a significant treatment $\times$ year interaction. We observed a general decline in the growth of forbs in the control plots from spring 2002 to spring 2003. Site affected the response of certain forb species (rock lupine, sagebrush false dandelion, longleaf phlox, largehead clover, and foothill deathcamas) to treatment but differences in soil attributes among sites were not significant or showed no consistent trends (Table 3).

There was no apparent relationship between response to treatment and taxonomic family or class (monocot versus dicot), and the five species that were not affected were from different families. The densities of three species (rock lupine, serrate balsamroot, spiny phlox) in the control plots were relatively stable over the course of our study. The rest of the native forb populations were highly variable from year to year in the control plots.

Plot photographs were analysed for live vegetation cover using VegMeasure software (Fig. 3). Three years after treatment, there was one-third less cover $(P<0.001)$ in treated plots $(11 \%)$ versus control plots $(17 \%)$. We attribute the difference in overall vegetation cover to perennial forbs as there were few annual forbs or perennial grasses present, and medusahead was senesced when the photographs were taken.

\section{Discussion}

Fletcher et al. (1996) reported that sulfometuron methyl negatively impacts a variety of plant species, even at a lower-thanrecommended application rate. In our study, a moderate rate of sulfometuron methyl had a significant effect on populations within the native plant community. We observed a lower overall forb density in spring 2003 versus spring 2002, although March-May 2003 precipitation (Fig. 4) was more than double that of March-May 2002, while temperatures over the same periods (Fig. 5) were similar (Western Regional Climate Center 2005). Perhaps those forb species that are phenologically or physiologically most susceptible to competition for spring moisture with medusahead had already been displaced, and it was the remaining forb species that contributed to the higher overall forb density observed in spring 2002. Although our focus was more on plant density than plant growth, we monitored the forb vegetative cover over the study period. Total vegetative cover, including targeted weeds and non-targeted native species, was lower on the sulfometuron methyl-treated plots. The difference was not significant given the fact that growth of certain species was stunted by sulfometuron methyl without killing them completely.

Fortunately, sulfometuron methyl can function as both a preemergent and early post-emergent herbicide for effective medusahead control when applied in autumn. Even though we applied sulfometuron methyl in autumn, not only to simulate typical medusahead control procedure, but also to avoid forb susceptibility to treatment, we still saw a significant decline in overall forb density. Avoiding damage to non-target species by using lower herbicide rates may still provide effective medusahead control if combined with site preparation. Removal of medusahead thatches by burning before applying herbicide in the autumn decreases medusahead cover the following year (Kyser et al. 2007; Sheley et al. 2007).

Perhaps future research will identify a combination of site preparation and reduced application rates of sulfometuron methyl that optimises medusahead control while minimising forb damage.

\section{Conclusion}

The benefit of medusahead control by sulfometuron methyl should be weighed against the damage to non-target species. Reducing forb density opens niches that may be filled by a more aggressive ecotype of the targeted weed or by a new invading species (Groves 1989). Avoiding damage to non-target species by spot-spraying is not practical because of the vastness of areas invaded by medusahead. It is imperative that yet-uninfested areas prone to medusahead invasion be managed to promote diverse, healthy plant communities in order to limit medusahead expansion and the potential loss of native forbs.

\section{Acknowledgements}

The authors acknowledge the Oregon Agricultural Experiment Station, Oregon State University, the USDA-Agricultural Research Service, and the Burns District of the USDI-Bureau of Land Management for support and funding. We thank Casey Pevey, Karl Hopkins, Valerie Knox, Berta Youti, and Lisa Wolf for field assistance. We would like also to acknowledge Dr Michael Borman and Dr Larry Larson for reviewing this paper.

\section{References}

Anderson, E. J., Borman, M. M., and Krueger, W. C. (1998). 'The Ecological Provinces of Oregon: a Treatise on the Basic Ecological Geography of the State.' Oregon Agricultural Experiment Station. Special Report 990. (Oregon State University: Corvallis.)

Bahm, M. A., Jensen, K. C., and Barnes, T. G. (2011). Herbicide and fire effects on Smooth Brome (Bromus inermis) and Kentucky Bluegrass (Poa pratensis) in invaded prairie remnants. Invasive Plant Science and Management 4, 189-197. doi:10.1614/IPSM-D-10-00046.1 
Booth, D. T., Cox, S. E., Fifield, C., Phillips, M., and Williamson, N. (2005). Image analysis compared with other methods for measuring ground cover. Arid Land Research and Management 19, 91-100. doi:10.1080/ 15324980590916486

Davies, K. W. (2010). Revegetation of Medusahead-invaded sagebrush steppe. Rangeland Ecology and Management 63, 564-571. doi:10.2111/ REM-D-09-00127.1

Davies, K. W., and Svejcar, T. J. (2008). Comparison of Medusaheadinvaded and non-invaded Wyoming big sagebrush steppe in southeastern Oregon. Rangeland Ecology and Management 61, 623-629. doi:10.2111/ 08-005.1

Donaldson, S., and Bowers, G. (1998). 'Weed Identification and Control Guide. Cooperative Extension.' (University of Nevada: Reno.)

DuPont Agricultural Products (2002). 'OUST Herbicide Product Label. EI DuPont de Nemours and Company.' (DuPont Agricultural Products: Wilmington.)

Fletcher, J. S., Pfleeger, T. G., Ratsch, H. C., and Hayes, R. (1996). Potential impact of low levels of chlorsulfuron and other herbicides on growth and yield of nontarget plants. Environmental Toxicology and Chemistry 15, 1189-1196. doi:10.1002/etc.5620150726

Groves, R. H. (1989). Ecological control of invasive terrestrial plants. In: 'Biological Invasions: a Global Perspective'. (Eds J. A. Drake, H. A. Mooney, F. Di. Castri, R. H. Groves, F. J. Kruger, M. Remanjek and M. Williamson.) pp. 437-462. (Wiley: New York.)

Harvey, J. Jr., Dulka, J. J., and Anderson, J. J. (1985). Properties of sulfometuron methyl affecting its environmental fate: aqueous hydrolysis and photolysis, mobility and adsorption on soils, and bioaccumulation potential. Journal of Agricultural and Food Chemistry 33, 590-596. doi:10.1021/jf00064a009

Hironaka, M. (1961). The relative rate of root development of cheatgrass and medusahead. Journal of Range Management 14, 263-267. doi: $10.2307 / 3894744$

James, J. J., Davies, K. W., Sherley, R. L., and Aanderud, Z. T. (2008). Linking nitrogen partitioning and species abundance to invasion resistance in the Great Basin. Oecologia 156, 637-648. doi:10.1007/s00442-0081015-0

Johnson, D. E., Louhaichi, M., and Vulfson, M. (2003). VegMeasure: a $\mathrm{C}^{++}$ computer program for field measurement of vegetative cover. In: 'Proceedings of 2003 Annual Conference, Technology: Converging at the Top of the World'. pp. 1-8. (ASPRS: Anchorage.)

Kyser, G. B., Ditomaso, J. M., Doran, M. P., Orloff, S. B., Wilson, R. G., Lancaster, D. L., Lile, D. F., and Porath, M. L. (2007). Control of medusahead (Taeniatherum caput-medusae) and other annual grasses with imazapic. Weed Technology 21, 66-75. doi:10.1614/WT-06-027.1

Louhaichi, M., Borman, M., and Johnson, D. E. (2001). Spacially located platform and aerial photography for documentation of grazing impacts on wheat. Geocarto International 16, 65-70. doi:10.1080/101060401 08542184

Louhaichi, M., Johnson, M. D., Woerz, A. L., Jasra, A. W., and Johnson, D. E. (2010). Digital charting technique for monitoring rangeland vegetation cover at local scale. International Journal of Agriculture and Biology $\mathbf{1 2}$, $406-410$.
Major, J., McKell, C. M., and Berry, L. J. (1960). 'Improvement of Medusahead-infested Rangeland.' University of California Agricultural Experiment Station. Leaflet 123. (University of California: Davis.)

McCullagh, P., and Nelder, J. A. (1989). 'Generalized Linear Models.' (Chapman and Hall: London.)

Monaco, T. A., Osmond, T. M., and Dewey, S. A. (2005). Medusahead control with fall and spring-applied herbicides in northern Utah foothills. Weed Technology 19, 653-658. doi:10.1614/WT-04-202R2.1

Pimentel, D. (2002). 'Biological Invasions: Economic and Environmental Costs of Alien Plant, Animal, and Microbe Species.' (CRC Press: Boca Raton.)

Russell, M. H., Saladini, J. L., and Lichtner, F. (2002). Sulfonylurea herbicides. Pesticide Outlook 13, 166-173. doi:10.1039/b206509f

SAS (2009). 'SAS/STAT User's Guide, Version 9.2.' (SAS Institute: Cary.)

SERA (Syracuse Environmental Research Associates, Inc.) (2004). 'Metsulfuron methyl - Human Heath and Ecological Risk Assessment Final Report.' TR 02-43-17-01b. 9 December 2004. (SERA: Syracuse.)

Sheley, R. L., Carpinelli, M. F., and Reever Morghan, K. J. (2007). Effects of imazapic on target and nontarget vegetation during revegetation. Weed Technology 21, 1071-1081. doi:10.1614/WT-06-131.1

Trubey, R. K., Bethem, R. A., and Peterson, B. (1998). Degradation and mobility of sulfometuron-methyl (Oust herbicide) in field soil. Journal of Agricultural and Food Chemistry 46, 2360-2367. doi:10.1021/ jf970745x

USDA Forest Service (2004). 'Sulfometuron Methyl: Human Health and Ecological Risk Assessment.' Final Report. (USDA Forest Service: Fayetteville.)

USDA Forest Service (2005). 'Environmental Assessment: Turnpike Pit Medusahead Control.' (USDA Forest Service: Paulina.)

USDA Forest Service (2007). 'Invasive Plant Treatments Final Environmental Impact Statement Deschutes and Ochoco National Forests, Crooked River National Grassland.' (USDA Forest Service: Bend.)

USDA Forest Service (2008). 'Olympic National Forest Final Environmental Impact Statement and Record of Decision Beyond Prevention: SiteSpecific Invasive Plant Treatment Project.' (USDA Forest Service: Olympia.)

USDI Bureau of Land Management. (2001). 'GIS Geodatabase: General Vegetation, General Soils.' (USDI Forest Service: Burns.)

Vallentine, J. F. (2004). Herbicides for plant control. In: 'Restoring Western Ranges and Wildlands, Vol. 2'. Gen. Tech. Rep. RMRS-GTR-136 Vol 1. (Eds S. B. Monsen, R. Stevens and N. L. Shaw.)pp. 99-99. (Department of Agriculture, Forest Service, Rocky Mountain Research Station: Fort Collins.)

Western Regional Climate Center (2005). Western Regional Climate Center, Climatological Data Summaries, Desert Research Institute, Reno, NV. Available at: www.wrcc.dri.edu/ (accessed 5 September 2011).

Whitson, T. D., Burrill, L. C., Dewey, S. A., Cudney, D. W., Nelson, B. E., Lee, R. D., and Parker, R. (2002). 'Weeds of the West.' 9th edn. (The Western Society of Weed Science. University of Wyoming: Jackson.) 